\title{
The Reading List 2012
}

\section{The RUSA CODES Reading List Council}

Reading List Council members: Sharron Smith, chair, Kitchener Public Library; Megan McArdle, vice chair, Berkeley Public Library; Alicia Ahlvers, Kansas City Public Library; Craig Clark, Akron, Ohio; Kathleen Collins, University of Washington Libraries, Seattle; Vicki Nesting, St. Charles Parish Library, Louisiana; Gillian Speace, NoveList, Durham, North Carolina; Miriam Tuliao, New York Public; Kimberly Wells, Denton Public Library; and Michelle Young, Hawaii State Public Library System.
$\mathbf{T}$

he expert readers' advisory librarians on the Reference and User Services Association's (RUSA) Reading List Council have selected their top picks for 2012 in eight popular genres: adrenaline titles (including suspense, thrillers, and action adventure), fantasy, historical fiction, horror, mystery, romance, science fiction, and women's fiction.

The council, which consists of twelve librarians who are experts in readers' advisory and collection development, selects one book from each of these genres, as well as a short list of honor titles-up to four per genre. The result is a list of recommended novels that will please die-hard fans as well as introduce new readers to the pleasures of genre fiction.

\section{ADRENALINE}

Watson, S. J. Before I Go To Sleep. Harper Collins. (ISBN: 9780-0620-6055-6)

Each morning, Christine wakes with no memory. From the clues she left herself, she tries to piece together her identity and sort lies from the truth. The unrelenting pace thrusts the reader into the confusion of a waking nightmare in which revelations of her past lead to a frantic crescendo.

\section{Read-Alikes}

- French, Tana. The Likeness.

- Lehane, Dennis. Shutter Island.

- Memento (Summit Entertainment, 2000).

\section{Short List}

- Bolton, S. J. Now You See Me. St. Martin's. (ISBN: 978-0312-60052-5).

- McEuen, Paul. Spiral. Dial Press. (ISBN: 978-0-385-34211-7).

- Hill, Reginald. The Woodcutter. Harper Collins. (ISBN: 9780-06-206074-7).

- Hurwitz, Gregg. You're Next. St. Martin's. (ISBN: 978-0312-53491-2).

\section{FANTASY}

Morgenstern, Erin. The Night Circus. Doubleday. (ISBN: 9780-385-53463-5).

Le Cirque des Rêves is utterly unique, disappearing at dawn in one town only to mysteriously reappear in another. 


\section{FROM COMMITTEES OF RUSA}

At the heart of the circus are two young magicians, involved in a competition neither completely understands. The dreamlike atmosphere and vivid imagery make this fantasy unforgettable.

\section{Read-Alikes}

- Clarke, Susanna. Jonathan Strange \& Mr. Norrell.

- Zafón, Carlos Ruiz. Shadow of the Wind.

- Prestige (Touchstone Pictures, 2006).

\section{Short List}

- Taylor, Laini. Daughter of Smoke and Bone. Little, Brown. (ISBN: 978-0-3161-3402-6).

- Grossman, Lev. The Magician King. Viking. (ISBN: 9780-670-02231-1).

- Rothfuss, Patrick. The Wise Man's Fear. DAW. (ISBN: 9780-7564-0473-4).

- Beukes, Lauren. Zoo City. Angry Robot. (ISBN: 978-085766-055-8).

\section{HISTORICAL FICTION}

Russell, Mary Doria. Doc. Random House. (ISBN: 978-14000-6804-3).

In the early days of Dodge City, a genteel, tubercular Southern dentist forges a friendship with the infamous Earp brothers. Combining historical details and lyrical language, this gritty psychological portrait of gunslinger Doc Holliday reveals how the man became the legend.

\section{Read-Alikes}

- Dexter, Pete. Deadwood.

- Kolpan, Gerald. Etta.

- Parker, Robert B. Gunman's Rhapsody.

\section{Short List}

- Smith, Dominic. Bright and Distant Shores. Pocket Books. (ISBN: 978-1-4391-9886-5).

- Penman, Sharon Kay. Lionheart. Putnam. (ISBN: 978-0399-15785-1).

- Towles, Amor. Rules of Civility. Viking. (ISBN: 978-0670-02269-4).

- Powning, Beth. The Sea Captain's Wife. Penguin. (ISBN: 978-0-452-29695-4).

\section{HORROR}

Koryta, Michael. The Ridge. Little, Brown. (ISBN: 978-0-31605366-2).

The unexplained death of an eccentric lighthouse keeper in the isolated Kentucky woods, followed by a mysterious threat to a nearby large cat sanctuary, prompt an investigation by a journalist and the local sheriff. Palpable evil and a sense of dread drive this chilling tale.

\section{Read-Alikes}

- Irwin, Stephen. The Dead Path.

- Buehlman, Christopher. Those Across the River.

- Lindqvist, John Ajvide. Harbor.

\section{Short List}

- Duncan, Glen. The Last Werewolf. Knopf. (ISBN: 978-0307-59508-9).

- Bohjalian, Chris. The Night Strangers. Crown. (ISBN: 9780-307-39499-6).

- Gregory, Daryl. Raising Stony Mayhall. Del Rey. (ISBN: 978-0-345-52237-5).

- Evans, Justin. The White Devil. Harper Collins. (ISBN: 978-0-06-172827-3).

\section{MYSTERY}

Higashino, Keigo. The Devotion of Suspect X. Minotaur. (ISBN: 978-0-312-37506-5)

An introverted mathematician matches wits with a brilliant former colleague to protect the neighbor he secretly adores from a murder charge. Although the reader knows the murderer's identity from the beginning, this unconventional Japanese mystery remains a taut psychological puzzle.

\section{Read-Alikes}

- Kirino, Natsuo. Out.

- Verdon, John. Think of a Number.

- Sherlock (BBC, 2010-2012).

\section{Short List}

- Gran, Sara. Claire DeWitt and the City of the Dead. Houghton, Mifflin. (ISBN: 978-0-547-42849-9).

- Cotterill, Colin. Killed at the Whim of a Hat. Minotaur. (ISBN: 978-0-312-56453-7). 
- Nesbø, Jo. The Snowman. Knopf. (ISBN: 978-0-30759586-7).

- Penny, Louise. A Trick of the Light. Minotaur. (ISBN: 9780-312-65545-7).

\section{ROMANCE}

Chase, Loretta. Silk is for Seduction. Avon. (ISBN: 978-0-06163268-6).

Ambitious dressmaker Marcelline Noirot will do almost anything to secure the patronage of the Duke of Clevendon's intended bride. Neither her calculated business plan nor his campaign of seduction can withstand the force of their mutual attraction. Witty banter and strong-willed characters make this a memorable tale.

\section{Read-Alikes}

- Hunder, Madeline. Dangerous in Diamonds.

- Hoyt, Elizabeth. The Raven Prince.

- Ivory, Judith. Untie My Heart.

\section{Short List}

- Harrison, Thea. Dragon Bound. Berkley. (ISBN: 978-0425-24150-9).

- Duran, Meredith. A Lady's Lesson in Scandal. Pocket. (ISBN: 978-1-4516-0693-5).

- Higgins, Kristin. My One And Only. Harlequin. (ISBN: 978-0-373-77557-6)

- James, Eloisa. When Beauty Tamed the Beast. Avon. (ISBN: 978-0-06-202127-4)

\section{SCIENCE FICTION}

Corey, James S.A. Leviathan Wakes. Orbit. (ISBN: 978-0-31612908-4)

The missions of a jaded cop and a dedicated ice hauler officer collide as the fate of humanity hangs in the balance. A mystery adds a noir touch to this space opera featuring deeply flawed yet heroic characters, non-stop action, and Earth versus Mars politics.

\section{Read-Alikes}

- Locke, M. J. Up Against It.

- Hamilton, Peter. Pandora's Star.

- McAuley, Paul J. The Quiet War.

\section{Short List}

- Miéville, China. Embassytown. Del Rey. (ISBN: 978-0345-52449-2).

- Rajaniemi, Hannu. The Quantum Thief. Tor. (ISBN: 9780-7653-2949-3).

- Cline, Ernest. Ready Player One. Crown. (ISBN: 978-0307-88743-6).

- Jordan, Hillary. When She Woke. Algonquin. (ISBN: 9781-56512-629-9).

\section{WOMEN'S FICTION}

Diffenbaugh, Vanessa. The Language of Flowers. Ballantine. (ISBN: 978-0-345-52554-3).

A former foster child struggles to overcome a past filled with abuse, neglect, and anger. Communicating through the Victorian language of flowers allows her to discover hope, redemption, and a capacity for love. Damaged, authentic characters create an emotional tension in this profoundly moving story.

\section{Read-Alikes}

- McLain, Paul (NF). Like Family.

- Humphreys, Helen. The Lost Garden.

- Fitch, Janet. White Oleander.

\section{Short List}

- Fay, Juliette. Deep Down True. Penguin. (ISBN: 978-0-14311851-0).

- Bauermeister, Erica. Joy for Beginners. Putnam. (ISBN: 978-0-399-15712-7).

- Brown, Eleanor. The Weird Sisters. Putnam. (ISBN: 9780-399-15722-6).

- Moriarty, Liane. What Alice Forgot. Penguin. (ISBN: 9780-14-104376-0). 